\title{
Efficacy of subcutaneous immunotherapy achieved with a whole-body extract of Pseudomyrmex ant. A case reported in a young woman, in Argentina
}

\author{
Raquel M Rodriguez ${ }^{1 *}$, Silvia G Irañeta ${ }^{1 \#}$, María L Olgiati ${ }^{2}$, Luciana L Soprano ${ }^{3}$, Krikor Mouchián ${ }^{1}$, Angel Alonso $^{1}$ and Vilma G Duschak $^{2 *}$ \\ ${ }^{1}$ División Alergia e Inmunología, Hospital de Clínicas José de San Martín, Universidad de Buenos Aires, Argentina \\ ${ }^{2}$ Instituto Nacional de Parasitología Dr. Mario Fatala Chaben, ANLIS-Malbrán, Ministerio de Salud, Argentina \\ \#These authors have contributed equally to this publication
}

\begin{abstract}
The aim of this work is to report for the first time a patient case with anaphylaxis by Pseudomyrmex acanthobius / favidulus ant sting, prepare an extract with the wholeant-body, to study their biochemical and immunological properties and to validate the efficacy of the subcutaneous immunotherapy with this non-commercial extract. An argentine woman patient, 19 years old, with background of allergic rhinitis and bronchial asthma in the childhood, suffered repeated episodes of anaphylaxis by non-identified insect's stings and previous immunotherapies treatment. The entomologic analysis revealed that the aggressor insect was an ant belonging to Pseudomyrmex genera and acanthobius or favidulus species. High serum total levels of IgE (202 UI/ml) were measured by ELISA and a positive 6-mm wheal and flare reaction (extract dilution 1/100000) was revealed by in vivo intradermal test. A sample of the extract proteins fraction was analysed by SDS-PAGE. The silver stained protein bands ranged since 20 to $220 \mathrm{kDa}$. The patient serum immune-recognized allergenic extract proteins at approximately 160 , 90 , and a double band at $42 / 46$ $\mathrm{kDa}$ prior to desensitization treatment by electro-blotting. Interestingly, post-specific-subcutaneous-immunotherapy the mentioned double band almost disappeared. After a 6-years-treatment, the total $\mathrm{IgE}$ serum values strongly decreased and the specific intradermal test was negative up to $1 / 10$ extract dilution. The tolerance to the treatment was good. Altogether, our findings revealed that the immunotherapy performed with the whole-body-Pseudomyrmex ant allergenic extract was highly effective and the IgE specific-double protein allergenic extract bands $(42 / 46 \mathrm{kDa})$ that disappeared after immunotherapy were responsible for the anaphylactic shock.
\end{abstract}

\section{Introduction}

Allergic reactions caused by ant's sting have a low incidence around the world, but these events represent a significant matter of health in regions where the mentioned Hymenoptera are endemic, as in South America. Although most allergic reactions to fire ants are caused by Solenopsis invicta, regarding ants from Pseudomyrmex genera, only two cases of anaphylaxis by P. ejectus have been described in USA. The identification of ants, other than Solenopsis invicta and Solenopsis richteri reported to cause adverse reactions in humans [16]. However, events due to the less common species Pseudomyrmex acanthobius or Pseudomyrmex flavidulus have not been registered to date.

In these cases, allergist follow-up is essential to investigate possible causes, to achieve a broad risk assessment, and to avoid future events by mounting personalized threat reduction schemes including, when possible, beginning allergen immunotherapy. However, although the establishment of Allergy institutional guidelines, there are still many fissures in the evidence base for anaphylaxis [1]. Regarding stinging insect hypersensitivity, a practice parameter update was designed, but not for drug promotion in pharmaceutical companies. Conversely, the fluctuating medical environment, but not all recommendations will be suitable for all patients [2]. Consciousness that species other than imported fire ants are capable to cause serious allergic or adverse anaphylactic (IgE-mediated) reactions, or anaphylactic-like, resembling anaphylaxis but of unknown mechanism, immediate reactions to ant stings or bites would drive to more quick evaluation and treatment, including further investigation of the medical entomology of these ants
Solenopsis invicta and Solenopsis richteri, that cause adverse reactions in humans. However, a varied group of ant species belonging to 6 different subfamilies including Formicinae, Myrmeciinae, Ponerinae, Ectatomminae, Myrmicinae, and Pseudomyrmecinae and 10 genera such as Solenopsis, Formica, Myrmecia, Tetramorium, Pogonomyrmex, Pachycondyla, Odontomachus, Rhytidoponera, Pseudomyrmex, and Hypoponera have been identified as other imported fire ants responsible for causing severe reactions [6]. Herein, we present a case of an argentine young woman patient, 19 years old, from a rural area, with background of allergic rhinitis and bronchial asthma in the childhood that presented repeated episodes of anaphylaxis during a 10-years period by a non-identified aggressor insect. The aims of this work are i) to report a patient case with anaphylaxis by Pseudomyrmex ant sting, ii) to prepare an extract with the specific whole-body ant,

iii) to study their biochemical and immunological properties and, iv) to validate the efficacy of the subcutaneous immunotherapy with this non-commercial extract.

*Correspondence to: Vilma G. Duschak, Instituto Nacional de Parasitología (INP) "Dr. Mario Fatala Chaben", ANLIS-Malbrán, Ministerio de Salud, Avenida Paseo Colon 568, Ciudad Autónoma de Buenos Aires (1063), Buenos Aires, Argentina, E-mail:vduschak@conicet.gov.ar

Key words: allergens, allergenic whole body-extracts ants, immunotherapy, Pseudomyrmex acanthobius, Pseudomyrmex favidulus

Received: December 19, 2018; Accepted: December 28, 2018; Published: December 31, 2018 


\section{Material and methods}

\section{Preparation of allergenic extract}

The extract was prepared following the Frugoni-Hansen method (1970) described elsewhere [7]. The ant-whole-bodies were degreased with ether followed by protein extraction. Pseudomirmex ant was extracted in phosphate-buffered saline (PBS), by stirring at $4^{\circ} \mathrm{C}$ in $1: 5(\mathrm{w} / \mathrm{v})$ ratios. After centrifugation at $4^{\circ} \mathrm{C}, 500 \mathrm{~g}$ for $40 \mathrm{~min}$, the clarified extract was dialyzed in PBS. Extracts were sterilized with Millipore filters (Bedford, MA, USA) $(0.22 \mathrm{~mm})$. Sterility controls were performed, and the extracts were frozen and stored at $-20^{\circ} \mathrm{C}$ Bradford's method was applied to determine the protein concentration of the extract, using bovine serum albumin as a standard solution [8].

\section{Patient clinical history}

Atopic patient suffering from sensitization to Pseudomyrmex ant, a young woman from a rural area of Buenos Aires was treated in the Department of Allergy and Immunology, Hospital de Clínicas, CABA, Argentina. She has a clinical history of allergic rhinitis and bronchial asthma in the childhood and presented repeated episodes of anaphylaxis during a 10 -years period. The patient showed elevated IgE levels and positive skin tests (dilution 1/100.000) of the elaborated ant extract (protein concentration $0.5 \mathrm{mg} / \mathrm{ml}$ ).

\section{Patients' sera}

Blood to be used for serum component analysis was obtained from the selected patient and control subjects by venipuncture, allowed to coagulate at $4^{\circ} \mathrm{C}$ and centrifuged at $1000 \mathrm{~g}$ for $15 \mathrm{~min}$. Non-haemolysed serum was separated, and aliquots were stored at $-70^{\circ} \mathrm{C}$ until use.

\section{Enzyme-linked immunosorbent assay}

sin paréntesis ELISA was performed on allergenic sample as described previously, with some modifications. Determination of specific IgE in human serum was performed as described previously $[9,10]$. Briefly, a microtitre plate was coated with $50 \mathrm{~mL}$ per well $(100$ $\mathrm{mg} / \mathrm{mL}$ in sodium carbonate buffer $\mathrm{pH}$ 9.6) of allergenic extract, incubated at $37^{\circ} \mathrm{C}$ for 90 min and blocked with $3 \%$ defatted milk in $0.1 \mathrm{M}$ PBS. After washing, the wells were incubated with $100 \mathrm{~mL}$ of a 1:10 dilution of human ant positive serum sera overnight at $37^{\circ} \mathrm{C}$. After additional washing with PBS-T, $100 \mathrm{~mL}$ of a 1:2000 dilution of peroxidase-conjugated goat anti-human IgE was added to each well for $2 \mathrm{~h}$ at $37^{\circ} \mathrm{C}$. The reaction was developed with o-phenylendiamine in citrate buffer, $\mathrm{pH} 4.6$, and hydrogen peroxide. The absorbance was read at $492 \mathrm{~nm}$ utilizing an automated ELISA reader (MR 700, Dynatech Lab, Chantilly, VA, USA). Each assay was run in three separately prepared duplicates.

\section{In vivo intradermal skin test}

Skin tests were carried out to measure reactivity to allergenic test and control extracts according to Aas and Belin (1972) [11]. Skin tests were performed in the morning and graded after $20 \mathrm{~min}$. based on the weal size of the histamine control, as it was conventionally established. On the day the skin test was performed, neither the allergic patient nor the controls were taking steroids, anti-histamines or immunosuppressive drugs. Informed consent is routinely obtained from all subjects before testing.

\section{Sodium dodecyl sulphate polyacrylamide gel electrophoresis (SDS-PAGE)}

25 micrograms of allergen single extract sample and standard molecular weight markers were electrophoresed in $10 \%$ polyacrylamide mini-gels in the presence of sodium dodecyl sulphate, according to Laemmli (1970) [12]. Protein bands from Pseudomirmex extract separated by SDS-PAGE were stained using a modified silver staining [13].

\section{Western blot}

SDS-PAGE-resolved ant extract proteins were electro-transferred onto a nitrocellulose membrane as described by Towbin et al, (1979) [14]. Briefly, the membranes strips were soaked for $90 \mathrm{~min}$ in blocking solution (TBS, $50 \mathrm{mM}$, Tris, $150 \mathrm{mM} \mathrm{NaCl}, \mathrm{pH} \mathrm{7.6}$, containing $3 \%$ non-fat dry milk), incubated with a $1 / 10$ dilution of Peudomirmexhypersensitive patient serum in $\mathrm{PBS}$ overnight at $4^{\circ} \mathrm{C}$ and then incubated with a 1:1000 diluted goat anti-human IgE-peroxidase conjugate for $90 \mathrm{~min}$ at room temperature. Sera from non-atopic subjects were taken as negative controls Colour development was performed with 4-chloro-1-naphthol and hydrogen peroxide in a methanol/PBS solution. Also, after blocking, membrane strips and tested with a 1:100 dilution of human serum followed by 90 -min incubation with rabbit antisera; strips were washed and treated with a goat anti-rabbit IgG antibody (1:2000), coupled to phosphatase alkaline for $90 \mathrm{~min}$ at room temperature. Sera from non-atopic subjects and normal rabbit sera served as negative controls. For IgG- and IgEprotein extract bands recognition behavior, strips were incubated prior and after immunotherapy by immunoblotting.

\section{Results}

The first step was the recognition of the culprit insect, the entomologic result revealed that it was an ant belonging to Pseudomyrmex genera and to two probable species P. acanthobius or P. flavidulus (Figure 1).

On the other hand, the initial biochemical determination by chemiluminescence showed high serum total levels of IgE (202 UI/ml). Regarding the ethical principles of the World Medical Associations' Declaration of Helsinky, after previous informed consent and patient anonymity preservation, methods approved by the Ethics Committee of the Hospital de Clínicas (ref number: 26 0168/07), were used. The in vivo intradermal test, using the specific whole-body ant prepared extract and the positive and negative controls were performed revealing a positive reaction in the $1 / 100.000$ extract dilution, in comparison with the positive and negative controls. The medical prescription consisted in education in avoidance of stinging insects and instructions of self-injectable epinephrine. In addition, a specific subcutaneous immunotherapy was performed by a conventional dosing schedule of

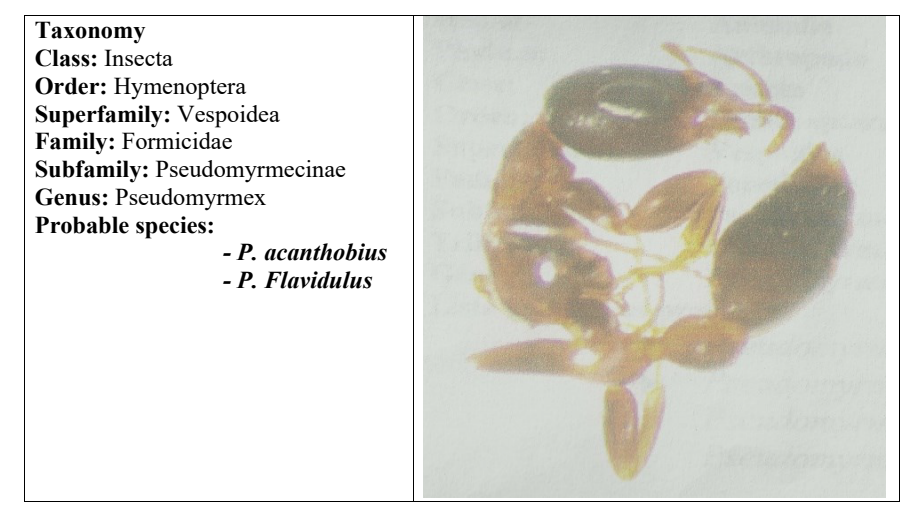

Figure 1. Taxonomy and photograph of the studied specimen. In the left, class, order superfamily, family, subfamily, genus and the two-probable species are shown; in the right, the photograph of the original specimen can be observed 
slow progression during a period of 6 years, using a whole-ant extract prepared in accordance to the method of Frugoni and Hansen (1970) [7].

On the other hand, the silver stained SDS-PAGE of this extract showed silver stained protein bands since 20 to $220 \mathrm{kDa}[12,13]$. In addition, western blotting analysis showed that the serum IgE of the patient recognized allergenic extract protein bands at approximately 160,90 , and a double band at $42 / 46 \mathrm{kDa}$, prior to desensitization treatment [14]. Interestingly, after immunotherapy the mentioned double band was almost completely abolished. By contrast, a double similar apparent molecular weight band was recognized by the serum IgG of the patient, only after treatment (Figure 2).

Tolerance to the treatment was good, although she suffered an accidental ant sting during the build-up phase causing anaphylaxis and a second one, during the maintenance phase with only local reaction. At the end of the treatment, the total $\operatorname{IgE}$ serum value decreased to normal levels and the in vivo intradermal test using the specific wholebody ant was negative up to $1 / 10$ extract dilution.

\section{Discussion}

Herein, we have reported a successful case of immunotherapy using a whole-body extract of Pseudomyrmex ant. This way of immunotherapy was able to induce the patient's tolerance to the ant. The ant abdomen portion may include many kinds of proteins that are not related to the patient's anaphylaxis, however, the whole body was selected as the best operative possible option, instead of the ant head portion alone, considering that whole-body preparation had been previously fruitful reported in literature [15]. In addition, fire ant whole-body extract, unlike other Hymenoptera whole-body extracts, retains its allergenic activity and is an adequate material for use in diagnostic testing and immunotherapy. Moreover, diagnosis of fire ant allergy has been readily made by the radioallergosorbent test (RAST) or by skin testing using fire ant whole-body extract. It has been reported that immunotherapy with fire ant whole-body extract in allergic individuals can prevent serious recurrent systemic reactions [16]. Some individuals fail to respond to testing or immunotherapy with imported fire ant whole-body extracts from three major U.S. commercial suppliers showing the urgent need for standardization

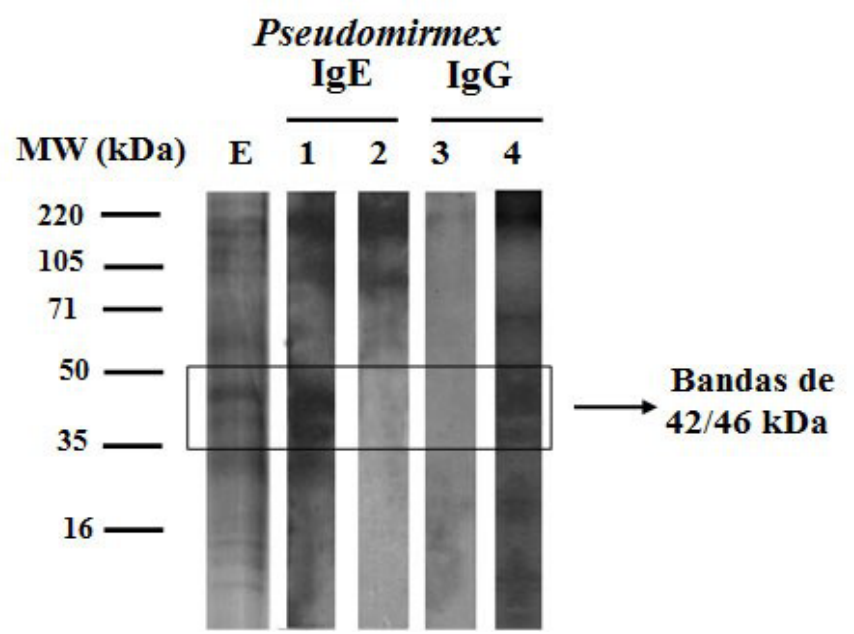

Figure 2. Immunerecognition analysis of Pseudomyrmex extract by Western Blot. $25 \mu \mathrm{g}$ of extract were loaded in each lane. At the left of the figure, silver stained SDS-PAGE $10 \%$ of Pseudomyrmex extract is shown; lanes 1 and 2 correspond to IgE and lanes 3 and 4 to IgG recognition, in both cases, prior and after immunotherapy treatment, respectively of allergenic extracts for diagnosis and treatment of imported fire ant sensitivity is well-known that in order to discard the possibility of microorganisms contamination during the preparation of the extract, potential infection was avoided by using the suitable filtration methods through filters according to Frugoni and Hansen methodology (1970), commonly used for preparation of allergenic extracts $[7,17]$.

Some decades ago, ant venom was described as a potent activator/ inactivator of components in both the classical and alternative complement pathways. Two factors, F1 and F2, have been identified in the venom of the tropical ant Pseudomyrmex sp. showing both trypsinlike and potent anti-complementary activities. In addition, when disc electrophoresis of native ant venom of the tropical ant Pseudomyrmex $s p$. was run on polyacrylamide gels, four glycoproteins were identified with periodic acid Schiff reagent Then, after gel filtration of the venom, in addition to the two the complement activators eluted at 175 and 32 $\mathrm{KDa}, \mathrm{F} 1$ and F2 were associated with a double band of glycoproteins species migrating together after electrophoresis on polyacrylamide gels, located between the bands of 175 and $32 \mathrm{KDa}$. F1 and F2 share a similar apparent molecular weight, in line with the IgE-immune reactive double band of $42 / 46 \mathrm{kDa}$. We can suggest that the double band identified in this work might correspond to the mentioned glycoproteins previously named F1 and F2 factors [18]. However, it requires further analysis.

Altogether, our findings revealed that the immunotherapy performed with the allergen extract prepared with whole-body of Pseudomyrmex ant was successful and that the double protein bands $(42 / 46 \mathrm{kDa})$ present in the extract, specifically recognized by $\operatorname{IgE}$ which disappeared after the immunotherapy, were responsible for the anaphylactic reactions. In line with these results, a protein pair of bands of similar apparent molecular weight $(42 / 46 \mathrm{kDa})$, specifically recognized by IgG, were observed after immunotherapy. Further proteomic studies should increase and shed light on our knowledge of these fascinating insects and the identification of specific allergenic ant extract proteins which is not the aim of the present study.

It is worth mentioning that we do not pretend to recommend this immunotherapy method to the readers, we only describe it as a unique case report. To recommend it, a statistical patient's number would be necessary to be evaluated. We believe that the case reports may be useful for readers to know the existence of this type of cases publications with good results in Latin American.

\section{Acknowledgement}

We would like to thank to Dr. Josens R. and Galvis Llanos J. for the technical assistance in the ant specimens' determination and to Leticia Orellana for technical assistance.

\section{Conflict of interest}

The authors have no conflict of interest to declare.

\section{References}

1. Muraro A, Roberts G, Worm M, Bilò M, Brockow K, et al. (2014) Anaphylaxis: guidelines. Allergy 69: 1026-1045. [Crossref]

2. Golden DB, Moffitt J, Nicklas RA, Freeman T, Graft DF, et al. (2011) Stinging insect hypersensitivity: a practice parameter update 2011. J Allergy Clin Immunol 127: 852854. [Crossref]

3. Graft DF (2006) Insect sting allergy. Med Clin North Am 90: 211-232. [Crossref]

4. Reques G (1998) Alergia a veneno de hormiga roja en España. Rev Esp Alergol Inmunol Clin 13: 39-40.

5. Hoffman DR (2010) Ant venoms. Curr Opin Allergy Clin Immunol 10: 342-346. [Crossref] 
Rodriguez RM (2018) Efficacy of subcutaneous immunotherapy achieved with a whole-body extract of Pseudomyrmex ant. A case reported in a young woman, in Argentina

6. Klotz JH, deShazo RD, Pinnas JL, Frishman AM, Schmidt JO, et al. (2005) Adverse reactions to ants other than imported fire ants. Ann Allergy Asthma Immunol 95: 418425. [Crossref]

7. Frugoni C, Hansen K (1970) Preparación de extractos alergénicos. En: Alergia Clinica. Hansen K, Werner M. Salvat. Barcelona.

8. Bradford MM (1976) A rapid and sensitive method for the quantitation of microgram quantities of protein utilizing the principle of protein-dye binding. Anal Biochem 72: 248-254. [Crossref]

9. Duschak VG, Riarte A, Segura EL, Lausella SA (2001) Humoral immune response to cruzipain and cardiac dysfunction in chronic Chagas disease. Immunol Lett 78: 135-142.

10. Iraneta SG, Seoane MA, Laucella SA, Apicella $C^{\sim}$, Alonso A et al. (2005) Antigenicity and immunocross-reactivity of orange tree pollen and orange fruit allergenic extracts. Int Arch Allergy Immunol 137: 265-272. [Crossref]

11. Aas K, Belin L (1972) Standardization of diagnostic work in allergy. Acta Allergol 27: 439-468.

12. Laemmli UK (1970) Cleavage of structural proteins during the assembly of the head of bacteriophage T4. Nature 227: 680-685. [Crossref]
13. Oakley B, Kirsch D, Morris R (1980) A simplified ultrasensitive silver stain for detecting proteins in polyacrylamide gels. Anal Biochem 105: 361-363.

14. Towbin H, Staehlin T, Gordon J (1979) Electrophoretic transfer of proteins from polyacrylamide gels to nitrocellulose sheets. Procedures and some application. Proc Natl Acad Sci USA 76: 4350-4354.

15. Meier EA, Whisman BA, Rathkopf MM (2006) Effect of imported fire ant extract on the degradation of mountain cedar pollen allergen. Ann Allergy Asthma Immunol 96: 30-32. [Crossref]

16. Paull BR (1984) Imported fire ant allergy. Perspectives on diagnosis and treatment Postgrad Med 76: 155-160. [Crossref]

17. Butcher BT, Reed MA (1988) Crossed immunoelectrophoretic studies of whole-body extracts and venom from the imported fire ant Solenopsis invicta. J Allergy Clin Immunol 81: 33-40. [Crossref]

18. Schultz DR, Arnold PI (1977) Venom of the ant Pseudomyrmex sp.: further characterization of two factors that affect human complement proteins. J Immunol 119: 1690-1699.

Copyright: (C2018 Rodriguez RM. This is an open-access article distributed under the terms of the Creative Commons Attribution License, which permits unrestricted use, distribution, and reproduction in any medium, provided the original author and source are credited. 